\title{
Seasonal variation in the maximum rate of leaf gas exchange of canopy and understory tree species in an Amazonian semi-deciduous forest
}

\author{
Kerrie M. Sendall1, George L. Vourlitis ${ }^{1 *}$, and Francisco A. Lobo ${ }^{2}$ \\ ${ }^{1}$ Biological Sciences Department, California State University, San Marcos, California, USA. \\ ${ }^{2}$ Departamento de Solos e Engenharia Rural, Universidade Federal de Mato Grosso, Cuiabá, Mato Grosso, Brazil. \\ * Corresponding Author: George L Vourlitis, Biological Sciences Department, California State University, San \\ Marcos, California, USA. Phone (760) 750-4119; Fax (760) 750-3440; email: georgev@csusm.edu \\ Received: 31 March 2009; Accepted: 04 June 2009
}

\begin{abstract}
Leaf gas exchange, water potential, and specific leaf area of two tropical semi-deciduous tree species, Brosimum lactescens S. Moore and Tovomita schomburgkii Planch \& Triana, were quantified to establish how these properties were affected by seasonal variations in rainfall and leaf canopy position. The study was conducted at a site near Sinop Mato Grosso, Brazil, which is located within the ecotone of savanna and tropical rain forest. Both species exhibited significant declines in leaf water potential $(\square\llcorner)$, specific leaf area, area- and mass-based light saturated photosynthesis and dark respiration, and maximum stomatal conductance during the dry-season, suggesting that leaf structural properties and gas exchange are significantly altered by drought that develops during the 4-month dry season. Internal leaf $\mathrm{CO}_{2}$ concentrations $\left(\mathrm{C}_{i}\right)$ were consistently lower during the dry season suggesting that the decline in maximum photosynthesis was due in part to a decline in stomatal conductance. However, seasonal variations in leaf gas exchange were larger for upper-canopy leaves, indicating an important interaction between drought stress and canopy position. The seasonal variation in leaf gas exchange and morphology was presumably due to a combination of drought stress and leaf lifespan. The results of this study suggest that drought has important implications for the leaf physiology and morphology of semi-deciduous Amazonian forest trees.
\end{abstract}

Key words: Brazil, Brosimum lactescens, climate change, ecotone, photosynthetic response, Tovomita schomburgkii, tropical transitional forest.

\section{INTRODUCTION}

Amazonian semi-deciduous forests are located within the savanna (cerrado)-rainforest ecotone along the southern and eastern borders of the Amazon Basin. Under current climate conditions the annual carbon budget of these forests appears to be in balance (Vourlitis et al. 2001, 2004, 2005; Keller et al. 2004: Priante et al. 2004). However, semi-deciduous forests of the southern Amazon Basin have experienced significant temperature increases over the last 30 years (Malhi and Wright 2005) and are also subjected to periodic warming and drought during El Niño (Potter et al. 2004). Drought can reduce net primary production (NPP), net ecosystem production (NEP), and evapotranspiration (Nepstad et al. 2002; Priante et al. 2004; Vourlitis et al. 2002, 2008), and cause an increase tree mortality (Condit et al., 1995). Thus, understanding how drought influences rates of $\mathrm{C}$ and $\mathrm{H}_{2} \mathrm{O}$ exchange is important for understanding current and future rates of NPP, NEP, and evapotranspiration.

Seasonal patterns of $\mathrm{C}$ and $\mathrm{H}_{2} \mathrm{O}$ exchange are affected by variations in leaf gas exchange, which in turn 
are regulated by a trade-off between seasonal patterns in rainfall and light availability. While these variations may be small in amplitude, they can significantly alter the physiological behavior of plants (Hogan et al. 1995; Miranda et al. 2005). In general, rates of photosynthesis increase considerably during the wet-season, even though an increase in cloudiness can limit light availability, because plants are exposed to high levels of soil water content, while declines in water availability during the dry season cause an overall reduction in leaf water potential and maximum photosynthesis (Pearcy 1987, Miranda et al. 1996, Sun et al. 1996, Miranda et al. 2005). However, the effects of seasonal drought are not likely to be similar for canopy and understory leaves and trees because of differences in physiology and resource allocation, phenology, and/or canopy growth microclimate (Boardman 1977; Cabral et al. 1996). For example, canopy trees are exposed to higher light, warmer temperatures, and lower atmospheric humidity than understory trees (Cabral et al. 1996), which can limit rates of gas exchange (Chaves et al. 1992). Leaves in the upper-canopy may have higher tissue $\mathrm{N}$ concentration, which will afford higher rates of maximum photosynthesis but at a higher respiratory cost (Reich and Walters 1994; Meir et al. 2001). Large trees may also have deep roots with access to water that can sustain high rates of gas exchange during the dry season (Nepstad et al. 1994).

Although a good deal of research has addressed how drought and light availability affect rates of photosynthesis in tropical forests, less is known about how these rates are affected by seasonality. This research is especially important in seasonally dry tropical forests, which experience significant temporal variation in rainfall and soil water content. Climate change from deforestation and fossil fuel combustion is anticipated to increase the magnitude and/or duration of seasonal drought (Cramer et al. 2005; Cowling et al., 2005), and semi-deciduous tropical forests are likely to be very sensitive climate change due to their transitional nature (Longman and Jenik 1992; Arris and Eagleson 1994; Vourlitis et al. 2005). Thus, the objective of this study was to evaluate how leaf gas exchange and related traits were influenced by seasonality and canopy position in a semi-deciduous, tropical transitional forest in the southern Amazon Basin. We hypothesize that seasonal variations in gas exchange will be large and correlated with variations in rainfall; however, the magnitude of the seasonal variation in gas exchange will be a function of canopy position.

\section{MATERIALS AND METHODS}

Site and species descriptions: The study was conducted in an intact, mature, upland (terra firme) semi-deciduous forest located near Sinop, Mato Grosso, Brazil (1124.75's; $55^{\circ} 19.50^{\prime} \mathrm{W}$ ) at an elevation of $423 \mathrm{~m}$ above sea level. This region is within the rainforest-savanna transition zone, which in northern Mato Grosso lies between 9 and $14^{\circ} \mathrm{S}$ latitude (Ackerly et al. 1989). Maximum canopy height is $25-28 \mathrm{~m}$, and a survey of the area indicated that there are 35 families and 80 species of trees with a diameter $\geq 10 \mathrm{~cm}$, including Protium sagotianum Marchland, Brosimum lactescens (S. Moore) C. C. Berg, Tovomita schomburgkii Planch \& Triana, and Qualea paraensis Ducke. However, three species, P. sagotianum (Burseraceae), B. lactescens (Moraceae), and T. schomburgkii (Clusiaceae), make up about $50 \%$ of individuals. Leaf area index (LAl) varies between $6.0 \mathrm{~m}^{2} \mathrm{~m}^{-2}$ at the end of the wet season (April) and $2.5 \mathrm{~m}^{2} \mathrm{~m}^{-2}$ at the end of the dry season (August) reflecting the semi-deciduous nature of the forest (Vourlitis et al. 2004; Sanches et al. 2008a). The soil is a quartzipsamments with a sandy, porous texture that drains rapidly after rainfall. The mean annual air temperature is approximately $24^{\circ} \mathrm{C}$, and average annual rainfall is about $2.0 \mathrm{~m}$ (Vourlitis et al. 2002). About half of the annual rainfall is received during the December-February wet season while only about $1 \%$ occurs during the June-September dry season (Vourlitis et al. 2002).

Two species located near a $40 \mathrm{~m}$ tall tower at the study site were selected for measurement due to their proximity to the tower or because they were short enough to be measured from the forest floor. Brosimum lactescens (Moraceae) is a semi-deciduous canopy emergent tree found in Amazonian evergreen and semi-deciduous forests (Ackerly et al. 1989, Lorenzi 2000). At our study site this species is $25-28 \mathrm{~m}$ tall with an average $( \pm 1 \mathrm{SD})$ diameter of $24.6 \pm 11.5 \mathrm{~cm}$. Tovomita schomburgkii (Clusiaceae) individuals are 4-17 m tall and are found in Amazonian forests in northeastern and central Brazil (Mariz 1974). At our study site these species account for $30 \%$ of all trees $\geq 10 \mathrm{~cm}$ diameter. 
Gas exchange measurements: Photosynthetic light-response curves were generated using a portable photosynthesis system (model LI-6400, LI-COR, Lincoln, NE., USA). One B. lactescens and three T. schomburgkii individuals were sampled during each season, because these trees were accessible either from the forest floor or from the tower at varying heights. In order to obtain multiple in situ measurements high within the forest canopy the leaves had to be readily accessible from the tower, which is why only one $B$. lactescens individual was sampled.

$B$. lactescens leaves were measured at canopy heights of 28,20 , and $12 \mathrm{~m}$, while $T$. schomburgkii leaves were measured at 12, 10, and $1 \mathrm{~m}$. Twelve light curves were generated at each of these heights during both the dry (July 2005) and wet (January 2006) seasons. To determine the effect of humidity on leaf gas exchange half of the light curves $(n=6)$ were generated at a relative humidity of $40 \%$ and half were generated at a relative humidity of $70 \%$. These humidity levels corresponded to a leaf-air vapor pressure deficit of 2.6 $\mathrm{kPa}$ and $1.5 \mathrm{kPa}$, respectively given the temperature conditions associated with the photosynthesis measurements, and are indicative of the mid-day relative humidity and atmospheric vapor pressure deficit that canopy leaves are exposed to during the dry and wet seasons, respectively (Vourlitis et al. 2004; 2005, 2008). Leaves were exposed to $400 \mu \mathrm{mol} \mathrm{mol}^{-1}$ $\mathrm{CO}_{2}$ and photosynthetic photon flux density (Q) levels of 2000, $1500,1000,500,250,100,50$ and $0 \mu \mathrm{mol}$ quanta $\mathrm{m}^{-2} \mathrm{~s}^{-1}$ using the LI-6400 LED light source. Chamber temperature was held at $28^{\circ} \mathrm{C}$ for all measurements.

Additional measurements: Leaf water potential $\left(\Psi_{\mathrm{L}}\right)$ was measured after every light curve using a pressure chamber (model 670, PMS Instrument Company, Albany, OR, USA) on fresh leaves adjacent to those measured for gas exchange. After measurement of $\Psi_{L}$ digital photos were taken of the leaves and the one-sided area was quantified using digital-image processing software (Sigma Scan Pro, version 5.0, Aspire Software International, Leesburg, VA, USA). Leaves were then dried at $70{ }^{\circ} \mathrm{C}$ for at least 48 hours to determine dry mass, and the projected specific leaf area (SLA) was calculated as the ratio of one-sided leaf area per unit dry weight.

Data analysis and photosynthesis modeling: Areabased photosynthetic data were fitted to a model that estimated net $\mathrm{CO}_{2}$ assimilation $\left(\mathrm{P}_{\text {net }} ; \mu \mathrm{mol} \mathrm{CO}_{2} \mathrm{~m}^{-2} \mathrm{~s}^{-1}\right)$ as a function of $\mathrm{Q}$ :

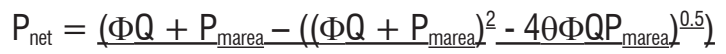

$2 \theta$

where $\Phi=$ the maximum quantum yield $\left(\mu \mathrm{mol} \mathrm{CO}{ }_{2} \mu \mathrm{mol} Q^{-1}\right)$, $P_{\text {marea }}=$ the maximum area-based rate of net photosynthesis $\left(\mu \mathrm{mol} \mathrm{CO} \mathrm{Cm}^{-2} \mathrm{~s}^{-1}\right)$, and $\theta=$ the dimensionless convexity of the curve (Thornley 1976, Ögren and Evans 1993). Nonlinear least squares regression was used to estimate the model coefficients $\left(\theta, \Phi\right.$ and $\left.P_{\text {marea }}\right)$. Maximum stomatal conductance $\left(\mathrm{g}_{\max }\right)$, and internal $\mathrm{CO}_{2}$ concentrations $\left(\mathrm{C}_{\mathrm{i}}\right)$ were calculated using the portable photosynthesis system using the same levels of $\mathrm{CO}_{2}$, irradiance, temperature, and relative humidity discussed above, while area-based dark respiration $\left(R_{\text {darea }}\right)$ was calculated when $Q=0 \mu$ mol quanta $\mathrm{m}^{-2} \mathrm{~s}^{-1}$. Massbased maximum photosynthesis $\left(P_{\text {mmass }}\right)$ and dark respiration $\left(R_{\text {dmass }}\right)$ rates were calculated by multiplying area-based rates by SLA.

Variations in $\Psi_{L}$ and SLA across season and canopy height were statistically evaluated using a two-factor analysis of variance. Multivariate analysis of variance (MANOVA) was used to determine whether there were differences in $P_{\text {marea, }}$, $P_{\text {mmass }}, R_{\text {darea }}, R_{\text {dmass, }}, g_{\text {max }}$, and $C_{i}$ across season, height, and relative humidity. The response of these variables as a function of season and canopy height did not differ with humidity, so in further analyses data were pooled across humidity. In the event of a significant season $x$ height interaction a one-way analysis of variance was used to determine whether differences existed across height and/or season.

\section{RESULTS}

Leaf water potential and specific leaf area: Leaf water potential $\left(\Psi_{\mathrm{L}}\right)$ declined during the dry season for $T$. schomburgkii and $B$. lactescens, but understory leaves experienced a smaller seasonal decline in $\Psi_{L}$ than midand upper-canopy leaves (Fig. 1). For example, the $\Psi_{\mathrm{L}}$ of $T$. schomburgkii mid-canopy leaves (12 $\mathrm{m}$ ) was approximately $0.3 \mathrm{MPa}$ lower during the dry season, while the average decline in $\Psi_{L}$ for $T$. schomburgkii understory leaves (10 $\mathrm{m}$ and $1 \mathrm{~m}$ ) was only about $0.15 \mathrm{MPa}$. The $\Psi_{\mathrm{L}}$ of $B$. lactescens uppercanopy (28 m) and mid-canopy (20 m and $12 \mathrm{~m}$ ) leaves was on average $0.65 \mathrm{MPa}$ lower during the dry season. 


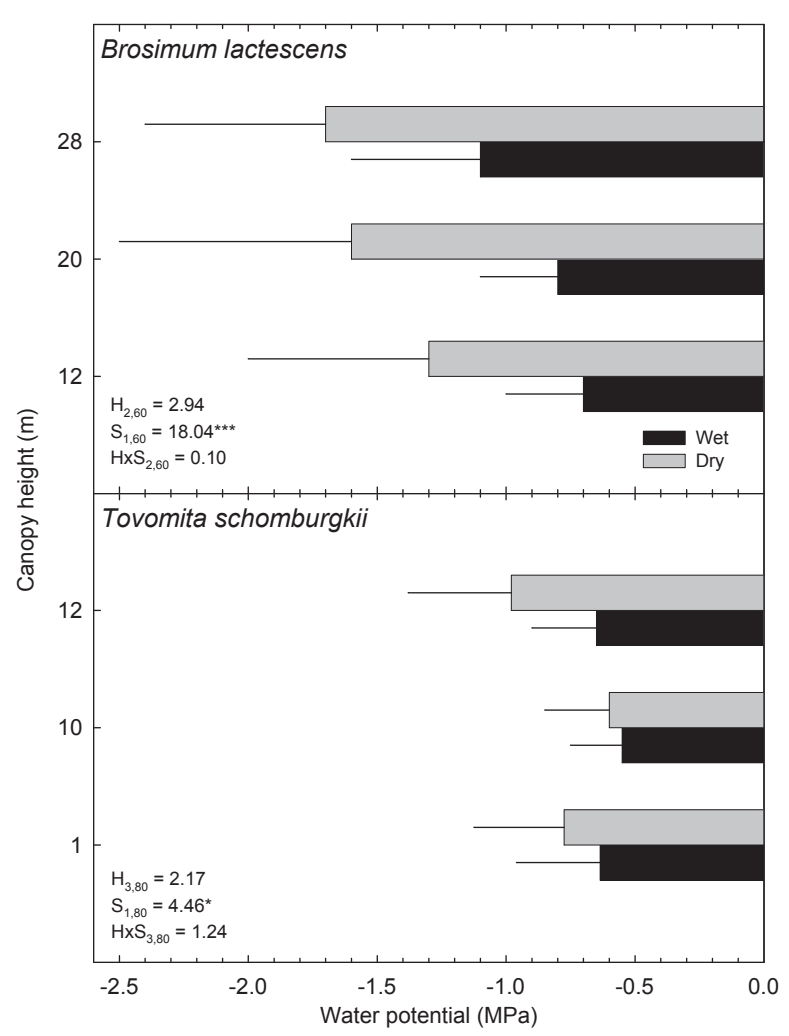

Figure 1. Mean $( \pm S D)$ leaf water potential for Tovomita schomburgkii and Brosimum lactescens during the wet season (black bars) and the dry season (grey bars). $\mathrm{N}=12$ measurements per canopy height, season, species combination. Also shown are the results ( $F$-statistics and degrees of freedom) from a 2-way ANOVA for differences between season (S), canopy height $(H)$, and the season $x$ height interaction $(\mathrm{H} \times \mathrm{S}) .{ }^{*}, \mathrm{p}<0.05 ;{ }^{* \star}, \mathrm{p}<0.01 ;{ }^{* \star *}$, $\mathrm{p}<0.001$.

The specific leaf area (SLA) of T. schomburgkii differed significantly among seasons and canopy heights; however, B. lactescens leaves only exhibited statistically significant differences in SLA on a seasonal basis (Fig. 2). During the dry season, the SLA for $T$. schomburgkii ranged from an average $( \pm S D)$ of $198 \pm 50.1 \mathrm{~cm}^{2} \mathrm{~g}^{-1}$ in the forest understory to $73 \pm 25.8 \mathrm{~cm}^{2} \mathrm{~g}^{-1}$ in the mid-canopy, while during the wet season, the average SLA of mid-canopy leaves increased by almost 30\%. Seasonal variation in SLA notwithstanding, the SLA of $T$. schomburgkii was negatively correlated with height. In contrast, seasonal variations in SLA were significantly positively correlated with leaf water potential for $B$. lactescens. The SLA of both mid-canopy and upper-canopy leaves of $B$. lactescens was approximately $83 \mathrm{~cm}^{2} \mathrm{~g}^{-1}$ during the dry season, but during the wet-season, the SLA of upper-canopy leaves remained at $85 \mathrm{~cm}^{2} \mathrm{~g}^{-1}$ while mid-canopy leaves showed an increase of more than $20 \%$ to $110 \pm 6.3 \mathrm{~cm}^{2} \mathrm{~g}^{-1}$ (Fig. 2).

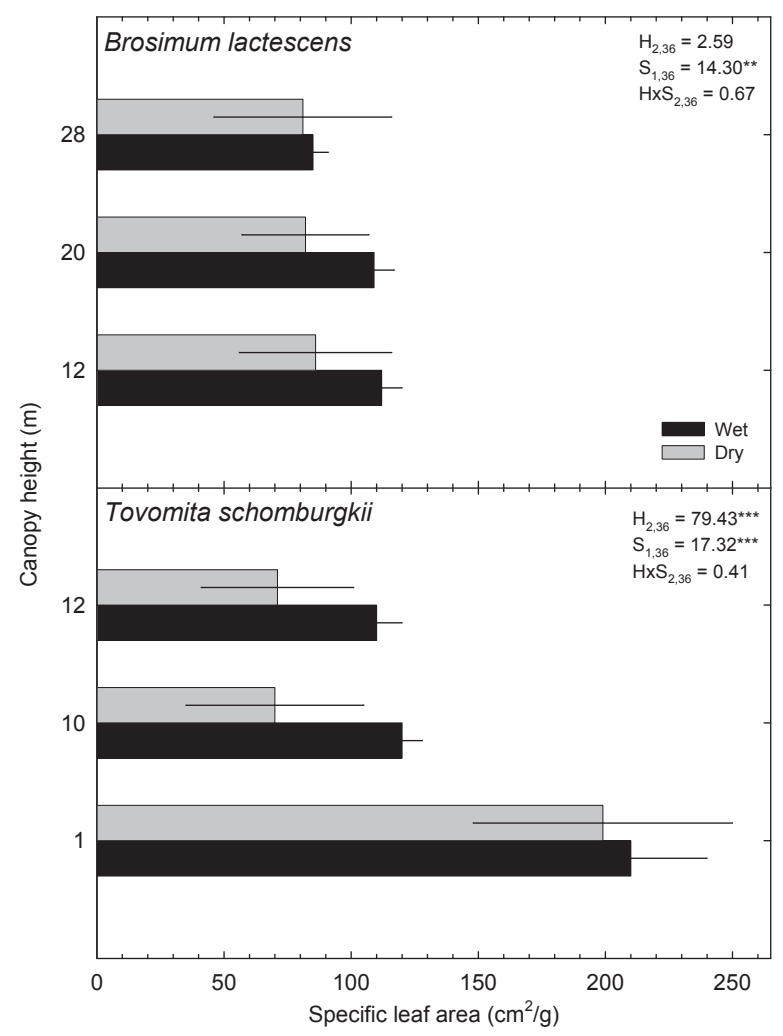

Figure 2. Mean $( \pm S D)$ specific leaf area for Tovomita schomburgkii and Brosimum lactescens during the wet season (black bars) and the dry season (grey bars). $\mathrm{N}=8$ measurements per canopy height, season, species combination. Also shown are the results (F-statistics and degrees of freedom) from a 2-way ANOVA for differences between season (S), canopy height $(H)$, and the season $x$ height interaction $(\mathrm{H} \times \mathrm{S}) .{ }^{*}, \mathrm{p}<0.05 ;{ }^{\star *}, \mathrm{p}<0.01$; ${ }^{* \star \star}$, $\mathrm{p}<0.001$.

Leaf gas exchange: The photosynthetic light-response of both tree species was well described by equation 1 , and the coefficient of determination $\left(r^{2}\right)$ values ranging between 0.95-0.97 (Table 1). The effect of humidity on the estimated coefficients was minimal; however, both species exhibited consistent seasonal differences in the quantum yield $(\Phi)$, maximum rate of light-saturated photosynthesis $\left(\mathrm{P}_{\text {marea }}\right)$, and the convexity index of the hyperbolic curve (Table 1). Values of the $\Phi$ and $P_{\text {marea }}$ were on average 2 and 1.7-times higher during the wet-season, while values of the convexity index were about $50 \%$ lower in the wet-season indicating a lower propensity of leaf photosynthesis to saturate at higher levels of $Q$. 
Table 1. Model coefficients quantum yield $\left(\Phi ; \mu \mathrm{mol} \mathrm{CO}_{2} \mu \mathrm{mol} \mathrm{Q}^{-1}\right)$, maximum photosynthesis $\left(\mathrm{P}_{\text {marea }} ; \mu \mathrm{mol} \mathrm{CO}_{2} \mathrm{~m}^{-2} \mathrm{~s}^{-1}\right)$, and convexity $(\theta$; dimensionless $)$ calculated for Tovomita schomburgkii and Brosimum lactescens trees at $40 \%$ and $70 \%$ relative humidity using equation 1 (see Methods). Also shown is the coefficient of determination $\left(r^{2}\right)$ and average estimated values for each species $x$ height combination ( $n=6$ measurements).

\begin{tabular}{|c|c|c|c|c|c|c|c|c|c|}
\hline \multicolumn{2}{|c|}{ 40\% Relative humidity } & \multicolumn{2}{|c|}{$\Phi$} & \multicolumn{2}{|c|}{$P_{\text {marea }}$} & \multicolumn{2}{|c|}{$\theta$} & \multicolumn{2}{|c|}{$r^{2}$} \\
\hline Species & Height & Dry & Wet & Dry & Wet & Dry & Wet & Dry & Wet \\
\hline \multirow[t]{3}{*}{ T. schomburgkii } & $1 \mathrm{~m}$ & 0.028 & 0.038 & 2.96 & 3.72 & 0.74 & 0.50 & 0.97 & 0.96 \\
\hline & $10 \mathrm{~m}$ & 0.033 & 0.038 & 4.31 & 5.47 & 0.84 & 0.70 & 0.98 & 0.96 \\
\hline & $12 m$ & 0.024 & 0.046 & 4.31 & 7.76 & 0.72 & 0.32 & 0.95 & 0.97 \\
\hline \multirow[t]{3}{*}{ B. lactescens } & $12 \mathrm{~m}$ & 0.028 & 0.040 & 4.10 & 5.32 & 0.51 & 0.24 & 0.97 & 0.95 \\
\hline & $20 \mathrm{~m}$ & 0.017 & 0.035 & 3.14 & 6.50 & 0.75 & 0.61 & 0.94 & 0.97 \\
\hline & $28 \mathrm{~m}$ & 0.012 & 0.043 & 3.77 & 7.26 & 0.67 & 0.14 & 0.91 & 0.95 \\
\hline \multicolumn{2}{|c|}{ 70\% Relative humidity } & \multicolumn{2}{|c|}{$\Phi$} & \multicolumn{2}{|c|}{$P_{\text {marea }}$} & \multicolumn{2}{|c|}{$\theta$} & \multicolumn{2}{|c|}{$r^{2}$} \\
\hline Species & Height & Dry & Wet & Dry & Wet & Dry & Wet & Dry & Wet \\
\hline \multirow[t]{3}{*}{ T. schomburgkii } & $1 \mathrm{~m}$ & 0.025 & 0.036 & 3.08 & 4.04 & 0.84 & 0.39 & 0.97 & 0.96 \\
\hline & $10 m$ & 0.032 & 0.046 & 4.10 & 6.29 & 0.90 & 0.33 & 0.96 & 0.97 \\
\hline & $12 m$ & 0.022 & 0.052 & 3.98 & 8.36 & 0.60 & 0.29 & 0.94 & 0.97 \\
\hline \multirow[t]{3}{*}{ B. lactescens } & $12 \mathrm{~m}$ & 0.032 & 0.052 & 4.11 & 5.73 & 0.56 & 0.34 & 0.97 & 0.96 \\
\hline & $20 \mathrm{~m}$ & 0.022 & 0.036 & 3.11 & 7.07 & 0.41 & 0.29 & 0.93 & 0.97 \\
\hline & $28 \mathrm{~m}$ & 0.011 & 0.041 & 4.49 & 8.01 & 0.56 & 0.32 & 0.92 & 0.96 \\
\hline
\end{tabular}

The results of the MANOVA indicated a significant main effect of season and height, and a significant season by height interaction on area- and mass-based light saturated photosynthesis $\left(P_{\text {marea }}, P_{\text {mmass }}\right)$, area- and mass-based dark respiration $\left(R_{\text {darea, }}, R_{\text {dmass }}\right)$, maximum stomatal conductance $\left(g_{\max }\right)$, and internal $\mathrm{CO}_{2}$ concentration $\left(\mathrm{C}_{\mathrm{i}}\right)$ (Table 2). Both species, regardless of their canopy position, exhibited significantly higher rates of $\mathrm{P}_{\text {marea }}$ during the wet season, though the smallest increases were seen in understory leaves (Fig. 3). Upper-canopy (20 and $28 \mathrm{~m}$ ) B. lactescens and mid-canopy (12 $\mathrm{m}) \mathrm{T}$. schomburgkii leaves exhibited the highest rates of $P_{\text {marea, }}$ with mean $( \pm S D)$ rates of $7.2 \pm 0.84$ and $7.9 \pm 0.81 \mu \mathrm{mol} \mathrm{CO} \mathrm{m}^{-2} \mathrm{~s}^{-1}$, respectively. Mid-canopy $T$. schomburgkii leaves experienced a $40-50 \%$ increase in $\mathrm{P}_{\text {marea }}$ during the wet season, while understory leaves exhibited smaller increases of $15-30 \%$. Upper-canopy leaves of $B$. lactescens experienced a $40-55 \%$ increase in $P_{\text {marea }}$, while mid-canopy leaves increased by $25-30 \%$. $P_{\text {marea }}$ increased with canopy height during both the wet and dry seasons in T. schomburgkii leaves, but increases with height were only observed during the wet season for $B$. lactescens. Rates of $P_{\text {mmass }}$ responded similarly to rates of $P_{\text {marea }}$ (data not shown), increasing significantly during the wet season at all canopy heights; however, canopy position did not have as large an effect on rates of $P_{\text {mmass }}$.

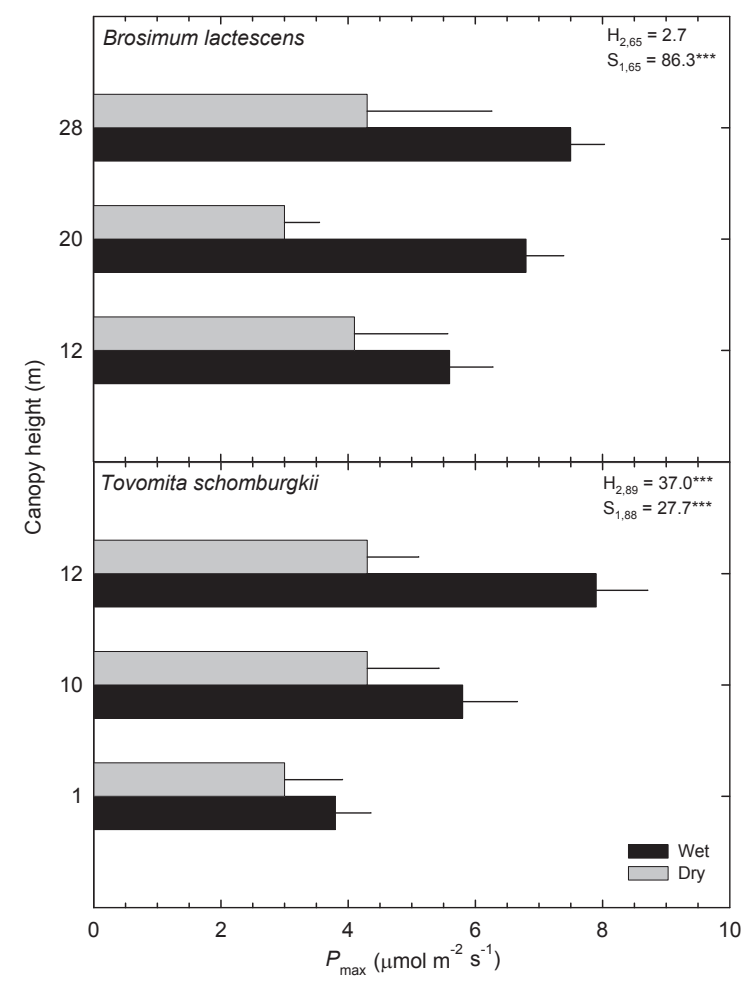

Figure 3. Mean $( \pm S D)$ area-based maximum net photosynthesis $\left(P_{\text {marea }}\right)$ for Tovomita schomburgkii and Brosimum lactescens during the wet season (black bars) and the dry season (grey bars). $\mathrm{N}=12$ measurements per canopy height, season, species combination. Also shown are the results (F-statistics and degrees of freedom) from individual 1-way ANOVAs for differences between season (S) and canopy height (H). ${ }^{*}, p<0.05 ;{ }^{* *}, p<0.01 ;{ }^{* *}, p<0.001$. Data were pooled across humidity because the leaf gas exchange response did not differ with humidity. One-way ANOVAs were conducted because MANOVA analyses revealed a significant season $x$ height interaction. 
Table 2. Response of area- and mass-based maximum photosynthesis $\left(P_{\text {marea, }}\right.$, $\left.\mathrm{P}_{\mathrm{mmass}}\right)$, area- and mass-based dark respiration, $\left(\mathrm{R}_{\text {darea, }}, \mathrm{R}_{\mathrm{dmass}}\right)$, maximum stomatal conductance $\left(\mathrm{g}_{\max }\right)$, and internal $\mathrm{CO}_{2}$ concentration $\left(\mathrm{C}_{i}\right)$ of Tovomita schomburgkii and Brosimum lactescens to variations in humidity, height, and season. Shown are the results of a Multivariate Analysis of Variance (MANOVA) including the probability of type-I error (p-value), the F-statistic calculated using Wilks' criterion, and the associated effect and error degrees of freedom (effect, error df).

\begin{tabular}{lccc}
\hline \multicolumn{1}{c}{ Tovomita schomburgkii } & $\boldsymbol{F}$-statistic & $\mathbf{d f}$ & $\mathbf{p}$ \\
\hline Humidity & 1.20 & 6,73 & 0.31 \\
Height & 141.48 & 12,146 & $<0.001$ \\
Season & 91.21 & 6,73 & $<0.001$ \\
Humidity x Height & 0.77 & 12,146 & 0.68 \\
Humidity x Season & 1.85 & 6,73 & 0.10 \\
Height x Season & 11.74 & 12,146 & $<0.001$ \\
Humidity x Height x Season & 0.77 & 12,146 & 0.68 \\
\hline Brosimum lactescens & F-statistic & $\mathrm{df}$ & $\mathrm{p}$ \\
\hline Humidity & 1.00 & 6,49 & 0.44 \\
Height & 41.98 & 12,98 & $<0.001$ \\
Season & 446.24 & 6,49 & $<0.001$ \\
Humidity x Height & 0.55 & 12,98 & 0.88 \\
Humidity x Season & 1.02 & 6,49 & 0.42 \\
Height x Season & 33.47 & 12,98 & $<0.001$ \\
Humidity x Height x Season & 0.26 & 12,98 & 0.99 \\
\hline
\end{tabular}

Average rates of $R_{\text {darea }}$ and $R_{\text {dmass }}$ were also consistently higher during the wet season for both species. The smallest seasonal variation in $\mathrm{R}_{\text {darea }}$ was observed in the understory and upper-canopy leaves, which experienced increases of 15$25 \%$ in the wet season, whereas mid-canopy leaves displayed seasonal increases of $30-50 \%$ (Fig. 4). $\mathrm{R}_{\text {darea }}$ also tended to increase with height in the forest canopy where leaves were exposed to more sunlight. The $\mathrm{R}_{\mathrm{dmass}}$ (data not shown) response to canopy height in both species was very similar to the response of $P_{\text {mmass }}$, with $B$. lactescens exhibiting very little change with canopy height within season and T. schomburgkii exhibiting large differences in the dry season only.

During the dry season, maximum stomatal conductance $\left(g_{\max }\right)$ was consistently less than $65 \mathrm{mmol} \mathrm{m}^{-2} \mathrm{~s}^{-1}$ at all canopy heights; however during the wet season, $g_{\max }$ increased considerably in leaves higher in the canopy that are exposed to higher levels of irradiance, reaching levels as high as 175 $\mathrm{mmol} \mathrm{m} \mathrm{m}^{-2} \mathrm{~s}^{-1}$ (Fig. 5). Understory leaves also experienced an increase in $g_{\max }$ during the wet-season, but it was much smaller than in leaves exposed to more sunlight. Mid-canopy (12 m) B. lactescens leaves exhibited an increase of 52$57 \%$ while the understory leaves of $T$. schomburgkii had the smallest increase of $18-42 \%$.
Values of $\mathrm{C}_{\mathrm{i}}$ were consistently higher in the wet-season than in the dry season (Fig. 5). The largest seasonal differences in $\mathrm{C}_{\mathrm{i}}$ were observed in mid- and upper-canopy plants, which exhibited increases of $7-12 \%$ in the wet season, while smaller increases were observed in the understory, ranging from $0-5 \%$. The average $( \pm \mathrm{SD})$ ratio of internal $\mathrm{CO}_{2}$ concentration $\left(\mathrm{C}_{\mathrm{i}}\right)$ to ambient atmospheric $\mathrm{CO}_{2}\left(\mathrm{C}_{\mathrm{a}}\right)$ was $0.64 \pm 0.03$ during the dry season and $0.71 \pm 0.03$ during the wet season. The optimal ratio for $\mathrm{C}_{3}$ plants is 0.70 (Wong et al. 1979), which indicates that photosynthesis may have been limited by available internal $\mathrm{CO}_{2}$ during the dry season (Miranda et al. 2005).

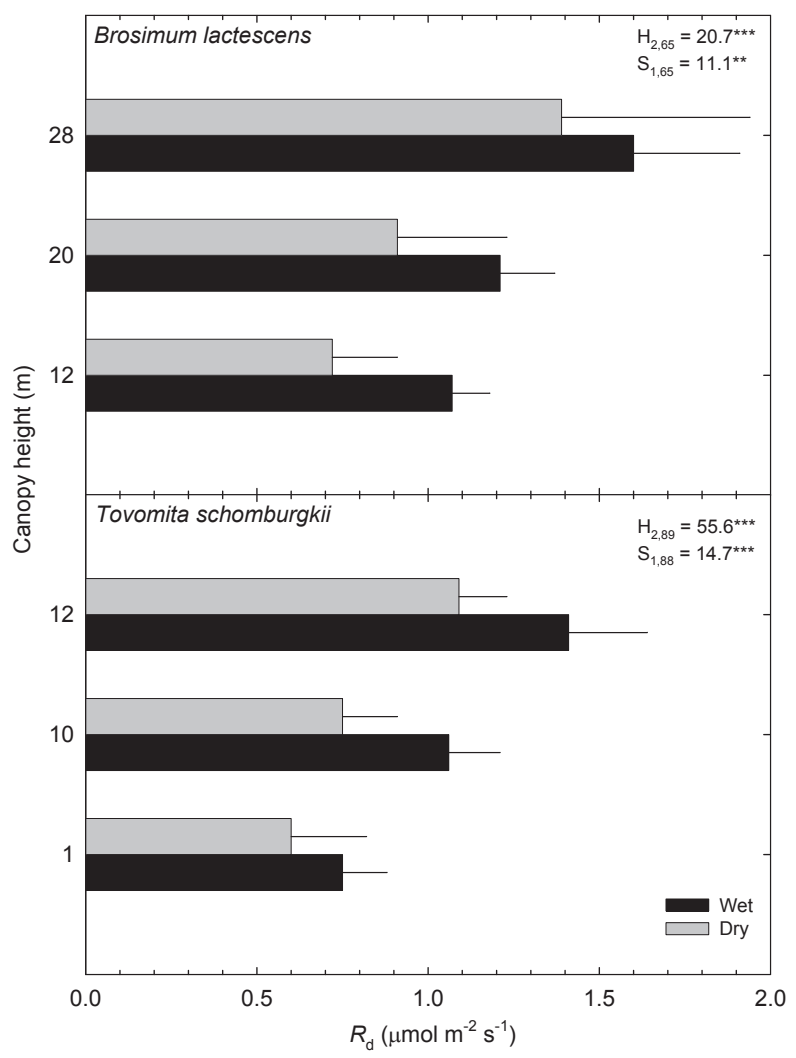

Figure 4. Mean $( \pm S D)$ area-based dark respiration $\left(R_{\text {darea }}\right)$ for Tovomita schomburgkii and Brosimum lactescens during the wet season (black bars) and the dry season (grey bars). $N=12$ measurements per canopy height, season, species combination. Also shown are the results (F-statistics and degrees of freedom) from individual 1-way ANOVAs for differences between season (S) and canopy height $(H) .{ }^{*}, p<0.05 ;{ }^{* *}, p<0.01 ;{ }^{* * *}, p<0.001$. Data were pooled across humidity because the leaf gas exchange response did not differ with humidity. One-way ANOVAs were conducted because MANOVA analyses revealed a significant season $\mathrm{x}$ height interaction. 


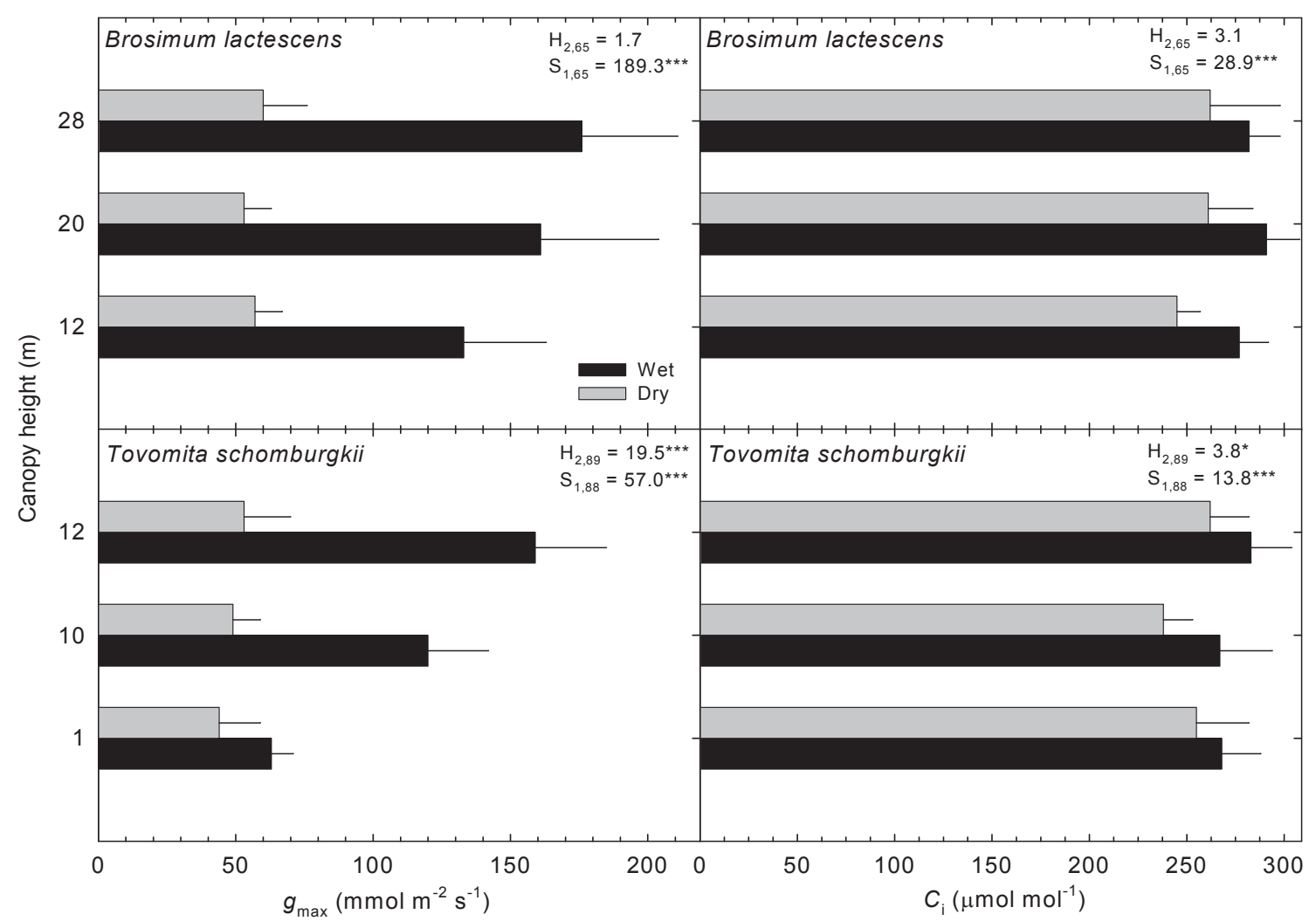

Figure 5. Mean $( \pm S D)$ area-based stomatal conductance ( $g_{\max }$; left-panels) and internal leaf $\mathrm{CO}_{2}$ concentration $\left(\mathrm{C}_{\mathrm{i}}\right.$; right-panels) for Tovomita schomburgkii and Brosimum lactescens during the wet season (black bars) and the dry season (grey bars). $\mathrm{N}=12$ measurements per canopy height, season, species combination. Also shown are the results ( $F$-statistics and degrees of freedom) from individual 1-way ANOVAs for differences between season (S) and canopy height $(\mathrm{H}) .{ }^{*}, \mathrm{p}<$ $0.05 ;{ }^{* *}, p<0.01 ;{ }^{* * *}, p<0.001$. Data were pooled across humidity because the leaf gas exchange response did not differ with humidity. One-way ANOVAs were conducted because MANOVA analyses revealed a significant season $\mathrm{x}$ height interaction.

\section{DISCUSSION}

We hypothesized that the leaf gas exchange of $T$. schomburgkii and $B$. lactescens would be significantly lower in response to seasonal drought; however, the decline in gas exchange would be larger for leaves in the upper canopy. Our results support this hypothesis, as all measures of leaf gas exchange were significantly lower during the dry season and the significant season $\mathrm{x}$ height interaction indicates that the sensitivity of seasonal drought was dependent on canopy position (Table 2).

Large seasonal variations in leaf gas exchange were expected given that the majority of the rainfall in this region falls during the wet season, while only $1 \%$ falls during the dry season (Vourlitis et al. 2002, Keller et al. 2004). Since the soils in the study site drain rapidly after rainfall, the forest can experience significant drought during the dry season (Malhi et al. 1998, Williams et al. 1998). With drought plants tend to close their stomata due to increasing evaporative demand at the surface of the leaf, which in turn decreases leaf photosynthetic rates (Meinzer et al. 1993), and even slight decreases in leaf water potential $\left(\Psi_{\mathrm{L}}\right)$ can trigger stomatal closing (Wright et al. 1992, Allen and Pearcy 2000). Interestingly, recent data suggests that rates of sap flow for $B$. lactescens and $T$. schomburgkii and whole-forest evapotranspiration may be relatively stable over seasonal cycles (Vourlitis et al. 2008), suggesting that plants have access a stable groundwater source (Nepstad et al. 1994). The stability in canopy evapotranspiration appears to be driven by seasonal trade-offs in net radiation (lower in the wet season due to cloud cover) and atmospheric evaporative demand (higher in the dry season due to lower atmospheric humidity). The high evaporative demand experienced during 
the dry season, coupled with possible limitations in hydraulic conductance, would lead to a decline in $\Psi_{\mathrm{L}}$ and $g_{\max }$ (Meinzer et al. 1993; Vourlitis et al. 2008).

Understory leaves of $T$. schomburgkii experienced the smallest seasonal variation in $P_{\text {marea }}, P_{\text {mmass }}$, and $g_{\text {max }}$, perhaps because these leaves are exposed to lower levels of sunlight and experience a lower evaporative demand (Whitehead et al. 1981, Tobin et al. 1999). These tree species also exhibited smaller seasonal variations in sap flow than taller trees in the forest canopy (Vourlitis et al. 2008), suggesting more consistent seasonal rates of leaf gas exchange. The internal $\mathrm{CO}_{2}$ concentrations $\left(\mathrm{C}_{\mathrm{i}}\right)$ of these understory leaves remained relatively constant between seasons, decreasing by less that $6 \%$ during the dry season, indicating relatively small stomatal limitations to $\mathrm{CO}_{2}$ diffusion. Upper-canopy $B$. lactescens leaves and mid-canopy leaves of both species exhibited substantially larger seasonal variation in $\mathrm{P}_{\text {marea }}$, $P_{\text {mmass }}$, and $g_{\max }$ than understory T. schomburgkii leaves. In all cases, the $\Psi_{L}$ in the mid- and upper-canopy was significantly higher during the wet season, so it appears that these leaves experienced less water stress during the wet season and were able to increase levels of stomatal conductance (Whitehead et al. 1981; Yordanov et al. 2000). However, the significant increase in photosynthetic rates that was observed in uppercanopy leaves does not appear to be fully explained by the increased diffusion of $\mathrm{CO}_{2}$ considering that the $\mathrm{C}_{\mathrm{i}}$ during the wet season increased by only as much as $12 \%$. Additionally, the increase in photosynthetic rates during the wet season did not coincide with increased leaf nitrogen (data not shown), which is known to affect the rate at which plants can fix $\mathrm{CO}_{2}$ for use in photosynthesis (Evans 1989).

Large seasonal variation in $P_{\text {marea }}, P_{\text {mmass }}$, and $g_{\text {max }}$ may have been caused in part by differences in leaf age (Hogan 1988; Reich et al. 1991; Osada et al. 2001). Leaves generally develop and become fully expanded during the wet season when photosynthetic rates, SLA, and stomatal conductance are highest (Miyaji et al. 1997). These leaf traits are negatively correlated with leaf age (Chabot and Hicks 1982; Field and Mooney 1986) and decline throughout the year until the dry season when leaf shedding occurs in response to drought (Reich and Borchert 1984; Sanches et al. 2008b).

Our data suggest that seasonal variations in rainfall distribution and drought significantly alter the leaf gas exchange of tropical understory and canopy tree species.
These data are consistent with other studies in tropical savanna (Franco 1998; Prado et al. 2004), semi-deciduous forest (Hogan et al. 1995; Miranda et al. 2005), and rainforest (de A. Sa et al. 1996; Bonal et al. 2000), and suggest that periodic drought represents a key control on tropical tree productivity. Given the anticipated $3-4^{\circ} \mathrm{C}$ increase in average annual temperature for the Brazilian tropics (Giorgi et al. 2001), the potential magnitude and/or duration of seasonal drought is likely to increase. Anticipated changes in precipitation are expected to be small, ranging from $0.0-1.0 \mathrm{~mm} \mathrm{~d}^{-1}$, but many models predict an intensification of the dry season in eastern South America (Malhi et al. 1999; Giorgi et al. 2001). Higher temperatures may lead to increased water stress (Malhi et al. 1999), and species that are more vulnerable to decreases in water potential will have a decreased gas exchange and likelihood of survival. Thus, changes in gas exchange may significantly alter the species composition and productivity.

Acknowledgments: This research was supported by the National Science Foundation, Division of Environmental Biology-Ecosystem Studies (DEB-0343964). Additional support was provided by the Conselho Nacional de Desenvolvimento Científico e Tecnológico (CNPq), California State University, San Marcos (CSUSM), and the Universidade Federal de Mato Grosso (UFMT). The authors thank 0. Borges and P. Bambi for field and laboratory assistance.

\section{REFERENCES}

Ackerly, D.D., W.W. Thomas, C.A.C. Ferreira and J.R. Pirani. 1989. The forestcerrado transition zone in southern Amazonia: results of the 1985 Projeto Flora Amazônica Expedition to Mato Grosso. Brittonia 41:113-128.

Allen, M.T. and R.W. Pearcy. 2000. Stomatal behavior and photosynthetic performance under dynamic light regimes in a seasonally dry tropical rain forest. Oecologia 122:470-478.

Arris LL \& PS Eagleson (1994) A water use model for locating the boreal/ deciduous forest ecotone in eastern North America. Water Res. R. 30: 1-9.

Boardman, N.K. 1977. Comparative photosynthesis of sun and shade plants. Annual Review of Plant Physiology 28:355-377.

Bonal, D., T. S. Barigah, A. Granier, and J. M. Guehl (2000) Late-stage canopy tree species with extremely low $\delta^{13} \mathrm{C}$ and high stomatal sensitivity to drought in the tropical rain forest of French Guiana. Plant, Cell and Environment 23: 445-459.

Cabral, O. M. R., A. L. C McWilliam and J. M. Roberts (1996) In-canopy microclimate of Amazonian forest and estimates of transpiration. Pages 207220 in Gash, J. H. C., C. A. Nobre, and R. M. Roberts, and R. I. Victoria (eds.) Amazonian climate and deforestation. J. M. Wiley and Sons, New York.

Chabot, B.F. and D.J. Hicks. 1982. The ecology of leaf life spans. Annual Review of Ecological Systems 13:229-259. 
Chaves MM, ML Osorio, J Osorio \& JS Pereira (1992) The photosynthetic response of Lupinus albus to high temperature is dependent on irradiance and leaf water status. Photosynthetica 27: 521-528.

Chazdon, R.L. and N. Fetcher. 1984. Light environments of tropical forests. In Physiological Ecology of Plants in the Wet Tropics. Eds. E. Medina, H.A. Mooney and C. Vasquez-Yanes. Junk, The Hague. pp 27-36.

Condit, R., S.P. Hubbell and R.B. Foster. 1995. Mortality rates of 205 Neotropical tree and shrub species and the impact of a severe drought. Ecological Monographs 65:419-439.

Cowling, S.A., R.A. Betts, P.M. Cox, V.J. Ettwein, C.D. Jones, M.A. Maslin and S.A. Spall. 2005. Modelling the past and future fate of the Amazonian forest. Pages 191-198 in Mahli, Y and O. L. Phillips (eds), Tropical Forests and Global Atmospheric Change, Oxford University Press, Oxford, UK.

Cramer, W., A. Bondeau, S. Schaphoff, W. Lucht, B. Smith, and S. Sitch. 2005. Twenty-first century atmospheric change and deforestation: Potential impacts on tropical forests. Pages 17-30 in Mahli, Y and O. L. Phillips, editors. Tropical Forests and Global Atmospheric Change. Oxford University Press, Oxford, UK.

de A. Sa., T. D., J. de P. R. da Costa, and J. M. Roberts, Forest and pasture conductances in southern Para, Amazonia, pages 241-264 in Gash, J. H. C., C. A. Nobre, J. M. Roberts \& R. L. Victoria (eds), Amazonian climate and deforestation. J. M. Wiley and Sons, New York, NY, USA, 1996.

Evans, J.R. 1989. Partitioning of nitrogen between and within leaves grown under different irradiances. Australian Journal of Plant Physiology 16:533548.

Field, C. and H.A. Mooney. 1986. The photosynthesis-nitrogen relationship in wild plants. In On the Economy of Plant Form and Function. Ed. T.J. Givnish. Cambridge University Press, Cambridge. pp 25-55.

Franco, A. C. 1998. Seasonal patterns of gas exchange, water relations and growth of Roupala montana, an evergreen savanna species. Plant Ecology 136: 69-76.

Giorgi, F., B. Hewitson, J. Christensen, M. Hulme, H. von Storch, P. Whetton, R. Jones, L. Mearns, and C. Fu. 2001. Regional climate information-Evaluation and projections. Pages 585-638 in Houghton, J. T., Y. Ding, D. J. Griggs, M. Nogour, P. F. van der Linder, X. Dai, K. Maskell, and C. A. Johnson, editors. Climate Change 2001: The Sceintific Basis. Intergovernmental Panel on Climate Change, Cambridge University Press, Cambridge, UK.

Hogan, K.P. 1988. Photosynthesis in two neotropical palm species. Functional Ecology 2:371-377.

Hogan, K.P., A.P. Smith and M. Samaniego. 1995. Gas exchange in six tropical semi-deciduous forest canopy tree species during the wet and dry seasons. Biotropica 27:324-333.

Keller, M., A. Alencar, G.P. Asner, B. Braswell, M. Bustamante, E. Davidson, T. Feldpausch, E. Fernandez, M. Goulden, P. Kabat, B. Kruijt, F. Luizão, S. Miller, D. Markewitz, A.D. Nobre, C.A. Nobre, N. Priante-Filho, H. Da Rocha, P. Silva Dias, C. Von Randow and G.L. Vourlitis. 2004. Ecological research in the large-scale biosphere-atmosphere experiment in Amazonia: Early results. Ecological Applications 14:S3-S16.

Longman, K.A. and J. Jenik. 1992. Forest-savanna boundaries: General considerations. In Nature and Dynamics of Forest-Savanna Boundaries. Eds. P.A. Furley, J. Proctor and J.A. Ratter. Chapman and Hall, Inc., New York. pp 3-20.

Lorenzi, H. 2000. Avores Brasileiras, Vol. 1. Instituto Plantarum de Estudos da Flora, Ltd., São Paulo, Brazil.

Malhi, Y. and J. Wright. 2005. Late-twentieth-century patterns and trends in the climate of tropical forest regions. In Tropical Forests and Global Atmospheric Change. Eds. Y. Malhi and O.L. Phillips. Oxford University Press, Oxford. pp 3-16.

Malhi, Y., A.D. Nobre, J. Grace, B. Kruijt, M.G.P. Pereira, A. Culf and S. Scott. 1998. Carbon dioxide transfer over a Central Amazonian rain forest. Journal of Geophysical Research D24:31593-31612.
Malhi, Y., D.D. Baldocchi and P.G. Jarvis. 1999. The carbon balance of tropical, temperate and boreal forests. Plant, Cell and Environment 22:715-740.

Mariz, G. 1974. Two new species of Tovomita Aublet (Guttiferae) from northeastern Brazil. Bulletin of the Torrey Botanical Club 101:367-371.

Meinzer, F.C., G. Goldstein, N.M. Holbrook, P. Jackson and J. Cavalier. 1993. Stomatal and environmental control of transpiration in a lowland tropical forest tree. Plant, Call and Environment 16:429-436.

Meir, P., J. Grace and A.C. Miranda. 2001. Leaf respiration in two tropical rainforests: constraints on physiology by phosphorus, nitrogen and temperature. Functional Ecology 15:378-387.

Miranda, A.C., H.S. Miranda, J. Lloyd, J. Grace, J.A. Mcintyre, P. Meir, P. Riggan, R. Lockwood and J. Brass. 1996. Carbon dioxide fluxes over a cerrado sensu stricto in central Brazil. In Amazonian deforestation and climate Eds. J.H.C. Gash, C.A. Nobre, J.M. Roberts and R.L. Victoria. J.M. Wiley and Sons, New York. pp 353-361.

Miranda, E.J., N. Priante, P.C. Priante, J.H. Campelo Jr., G.S. Suli, C.L. Fritzen and G.L. Vourlitis. 2005. Leaf and forest $\mathrm{CO}_{2}$ exchange of a transitional tropical forest in southern Amazonia. Journal of Tropical Ecology 21:451-460.

Miyaji, K., W.S. Da Silva and P.T. Alvim. 1997. Productivity of leaves of a tropical tree, Theobroma cacao, grown under shading, in relation to leaf age and light conditions within the canopy. New Phytologist 137:463-472.

Nepstad DC et al. (2002) The effects of partial throughfall exclusion on canopy processes, aboveground production, and biogeochemistry of an Amazon Forest. Journal of Geophysical Research 107(D20): 8085, doi: 10.1029/2001JD000360.

Ögren, E. and J.R. Evans. 1993. Photosynthetic light-response curves I. The influence of $\mathrm{CO}_{2}$ partial pressure and leaf inversion. Planta 189:182-190.

Osada, N., H. Takeda, A. Furukawa and M. Awang. 2001. Leaf dynamics and maintenance of tree crowns in a Malaysian rain forest stand. Journal of Ecology 89:774-782.

Pearcy, R.W. 1987. Photosynthetic gas exchange responses of Australian tropical forest trees in canopy, gap and understory micro-environments. Functional Ecology 1:169-178.

Potter C, S Klooster, M Steinbach, PN Tan, V Kumar, S Shekhar \& CR Carvalho (2004) Understanding global teleconnections of climate to regional model estimates of Amazon ecosystem carbon fluxes. Glob. Chan. Biol. 10: 693-703.

Prado, C. H. B. A., Z. Wenhui, M. H. C. Rojas, and G. M. Souza. 2004. Seasonal leaf gas exchange and water potential in a woody cerrado species community. Brazilian Journal of Plant Physiology 16: 7-16.

Priante-Filho, N., G.L. Vourlitis, M.M.S. Hayashi, J. de S. Noguiera, J.H. Campelo Jr., P.C. Nunes, L.S.E. Sousa, E.G. Couto, W. Hoeger, F. Raiter, J.L. Trienweiler, E.J. Miranda, P.C. Priante, C.L. Fritzen, M. Lacerda, L.C. Pereira, M.S. Biudes, G.S. Suli, S. Shiraiwa, S.R. Do Paulo and M. Silveira. 2004 Comparison of the mass and energy exchange of a pasture and a mature transitional tropical forest of the southern Amazon Basin during a seasonal transition. Global Change Biology 10:863-876.

Reich, P.B. and M.B. Walters. 1994. Photosynthesis-nitrogen relations in Amazonian tree species. Oecologia 97:73-81.

Reich, P.B. and R. Borchert. 1984. Water stress and tree phenology in a tropical dry forest in the lowlands of Costa Rica. Journal of Ecology 72:61-74.

Reich, P.B., C. Uhl, M.B. Walters and D.S. Ellsworth. 1991. Leaf lifespan as a determinant of leaf structure and function among 23 amazonian tree species. Oecologia 86:16-24.

Sanches L, NLR Andrade, JS Nogueira, MS Biudes \& GL Vourlitis (2008a) Índice de área foliar em floresta de transição Amazonia cerrado em diferentes médotos de estimative. Ciência e Natura 30: 57 - 69

Sanches L, CMA Valentini, OB Pinto Júnior, JS Nogueira, GL Vourlitis, CJ Silva, P Bambi, \& FA Lobo (2008b) Seasonal and interannual litter dynamics of a tropical semi-deciduous forest of the southern Amazon Basin, Brazil. J. Geophys. R.-Biogeosciences, in press. 
Sun, J., J.N. Nishio and T.C. Vogelmann. 1996. High-light effects on $\mathrm{CO}_{2}$ fixation gradients across leaves. Plant, Cell and Environment 19:1261-1271.

Thornley, J.H.M. 1976. Mathematical models in plant physiology. Academic Press, London. pp 92-110.

Tobin, M.F., O.R. Lopez and T.A. Kursar. 1999. Responses of tropical understory plants to a severe drought: tolerance and avoidance of water stress. Biotropica 31:570-578.

Vourlitis, G.L., N. Priante-Filho, M.M.S. Hayashi, J.S. Noguiera, F.T. Caseiro and J. Holanda Campelo. 2001. Seasonal variations in the net $\mathrm{CO}_{2}$ exchange of a mature Amazonian transitional tropical forest (cerradão). Functional Ecology 15:388-395.

Vourlitis, G.L., N. Priante-Filho, M.M.S. Hayashi, J.S. Noguiera, F.T. Caseiro and J. Holanda Campelo. 2002. Seasonal variations in the evapotranspiration of a transitional tropical forest of Mato Grosso, Brazil. Water Resources Research 38:1-11.

Vourlitis, G.L., N. Priante-Filho, M.M.S. Hayashi, J.S. Noguiera, F. Raiter, W. Hoegel and J.H. Campelo. 2004. Effects of meteorological variations on the $\mathrm{CO}_{2}$ exchange of a Brazilian transitional tropical forest. Ecological Applications 14:S89-S100.

Vourlitis, G.L., J.S. Nogueira, N. Priante-Filho, W. Hoeger, F. Raiter, M.S. Biudes, J.C. Arruda, V.B. Capistrano, J.L.B. Faria and F.A. Lobo. 2005. The sensitivity of diel $\mathrm{CO}_{2}$ and $\mathrm{H}_{2} \mathrm{O}$ vapor exchange of a tropical transitional forest to seasonal variation in meteorology and water availability. Earth Interactions 9: 9-027.

Vourlitis, G.L., J.S. Nogueira, F.A. Lobo, K.M. Sendall, J.L.B. Faria, C.A.A. Dias, and N.L.R. Andrade. 2008. Energy balance and canopy conductance of a tropical semi-deciduous forest of the southern Amazon Basin. Water Resources Research 44, W03412, doi: 10.1029/2006WR005526.

Whitehead, D., D.U.U. Okali and F.E. Fasehun. 1981. Stomatal response to environmental variables in two tropical forest species during the dry season in Nigeria. Journal of Applied Ecology 18:571-587.

Williams, M., Y. Malhi, A.D. Nobre, E.B. Rastetter, J. Grace and M.G.P. Pereira. 1998. Seasonal variation in net carbon exchange and evapotranspiration in a Brazilian rain forest: a modeling analysis. Plant, Cell and Environment 21:953968.

Wong, S.C., I.R. Cowan and G.D. Farquar. 1979. Stomatal conductance correlates with photosynthetic capacity. Nature 282:424-426.

Wright, S.J., J.L. Machado, S.S. Mulkey and A.P. Smith. 1992. Drought acclimation among tropical forest shrubs (Psychotria, Rubiaceae). Oecologia 89:457-463

Yordanov, I., V. Velikova and T. Tsonev. 2000. Plant responses to drought, acclimation, and stress tolerance. Photosynthetica 38:171-186. 